\title{
NÉPI ÉPÍTÉSZET A KÁRPÁT-MEDENCE ÉSZAKKELETI
} TÉRSÉGÉBEN

\section{(A Miskolcon 1989. május 15-16-án megrendezett konferencia anyaga) Szerkesztette: Cseri Miklós - Balassa M. Iván - Viga Gyula}

\section{Miskolc-Szentendre 1989. 361. o.}

A miskolci Herman Ottó Múzeum és a szentendrei Szabadtéri Múzeum szervezésében megtartott konferencia elôadásait tartalmazza ez a rendkivül igényes megjelenésú kötet. A népi építészet a hagyományos néprajz egyik legjobban kutatott, leginkább feltárt területei közé tartozik, a megrendezett konferencia, s az ott elhangzottakból összeállított kötet mégis arra vállalkozik, hogy ezekhez az ismeretekhez tegyen hozzá, újabb adatokkal szolgáljon eddigi ismereteink kiegészítésére, vagy éppen - háztípusokra vonatkozó - elméletek megcáfolására.

Nemcsak magyarországi, hanem Csehszlovákiából és (az akkori) Szovjetunióból érkezett régészek, történészek, néprajzosok fejtik ki álláspontjukat, számolnak be legújabb kutatási eredményeikrốl.

A kötet 22 - sok esetben - gazdagon illusztrált tanulmányt tartalmaz különbözổ szempontok alapján közelítve meg a Kárpátmedence északkeleti térségének népi építészeti problémáit.

Az elsổ három tanulmány régészek tollából származik. Alojz Habovstiak a középkori szlovákiai népi építészet tanulmányozásához szolgál régészeti adalékokkal, kiemelve a parasztházak és a hozzájuk tartozó gazdasági épületek, valamint az udvarházak, azaz a kisnemesi lakóhelyek régészeti kutatásokból megismerhetố sajátosságait, hangsúlyozva a kutatási téma interdiszciplinaritásának fontosságát. Fodor István és Wolf Mária a középkori magyar lakóház fejlổdéstörténetéhez füz megjegyzéseket, az ország különbözổ (Fodor István példái esetében az északkeleti-Kárpátok térségétốl némileg eltérố) területeirốl származó legújabb ásatási eredményeket ismertetve.

Balassa M. Iván tanulmánya a terület lakóházfejlốdésének állomásait vázolja fel, figyelembe véve a régészeti vizsgálatok, valamint a néprajzi kutatások eredményeit a 10-16. század között. Barabás Jenổ a 17-18. századi innovációs jelenségeket veszi sorra, amelyek szerepet játszottak a vidék jellegzetes építészeti karakterének kialakulásában. Elsôsorban gazdasági épületekre fordítja figyelmét, a házelemek közül a tetôszerkezetet és a tetôfedõanyagokat emeli ki. Hangsúlyozza, hogy az eltérések nem az etnikus sajátosságokban, hanem a különbözổ történeti rétegekben, vagyoni különbségekben, természeti adottsági eltérésekben, a polgárosodás eltérô fokában és stílusáramlatokban mutatkoznak meg.

Dám László a ,,szamosi házterület'-nek nevezett régió belsổ táji tagolódásának és más házvidékekkel való kapcsolatának néhány kérdésével foglalkozik, rendszerezve a házformák, a tüzelốberendezések eltérő típusait és a lakásbelsốk sajátosságait is. Gunda Béla a kulturális áramlat, a társadalom és az etnikum szerepét vizsgálja az északkeleti-Kárpátoképítkezésében, az etnikus sajátosságoknak és különbségeknek - Barabás Jenôvel szemben - sokkal nagyobb jelentôséget tulajdonítva. Hangsúlyozza, hogy a terület paraszttelkein a különbözổ korú, egymástól eltérổ kultúrrétegbe tartozó építmények a 20 . század elsố évtizedeire a parasztgazdaságok mechanizmusának megfelelôen funkcionális egységet alkottak.

A térség különbözổ etnikumainak sajátosságaival foglalkozó tanulmányok sorában Vác- 
lav Froleca kárpáti-Duna menti-, balkáni kapcsolatokat vizsgálva a 19. század végi, 20. század eleji hagyományos parasztházak fejlôdésében kilenc alapformát különböztet meg, $\mathrm{s}$ ezeknek elemzi a térség országaiban való elterjedtségét. Miroslav Sopoliga a Kárpátok ukránlakta területein vizsgálja a parasztház jellegzetes vonásait, három alapvetổ regionális típust határoz meg, s hangsúlyozza a különbözố kultúrák - házformákban is megnyilvánuló-folyamatos érintkezését, szimbiózisát. Hasonló megállapításra jut Ivan Vasziljevics Dragun kárpátaljai magyarság népi építészeti sajátosságait elemzổ tanulmánya is. Hodinka Antal kárpátukrán népi építészetre vonatkozó jegyzetei alapján érdekes tudománytörténeti adalékokkal szolgál Páll István és Udvari István közös tanulmánya, Jan Botík írása pedig Szlovákia német nyelvszigeteinek építészeti hagyományaival foglalkozik.

A tüzelốberendezések eltérố típusainak segítségével mutatja be a táji jellegzetességek keveredését Északkelet-Magyarország 18-19. századi népi építkezésében Páll István tanulmánya, Sona Kovacevicova pedig Szlovákia múltjában vizsgálja a népi és városi építészet közötti kapcsolatokat, hangsúlyozva, hogy ezek mindig is meglévô kapcsolatok voltak, hogy az építészeti különbségek az eltérố gazdasági, társadalmi- és munkaformáknak köszönhetổen, ezekkel szoros összefüggésben alakultak ki, s hogy az etnikai és vallási hovatartozás meghatározó tényezô.

Kecskés Péter egy településtípus, a térség mezốvárosi lakóházainak alaprajzi típusait idôrendben mutatja be, Cseri Miklós pedig egy társadalmi réteg, a kisnemesség építészetének sajátos vonásaival foglalkozik, a falazat, a födém, a tetőszerkezet, a nyílászárók, az alaprajz és a tornác típusainak megismertetésére koncentrálva.

Nehezen illeszthetổ a kötet koncepciójába Hoffmann Tamás tömör, summás, az emeletes parasztház európai elterjedtségét felvázoló, kultúrtörténeti írása, amely mintegy összegzésként megállapítja: ,,..a parasztházak emeletei a kultúra régióiban épültek: a városi polgárházak színvonalát akarták lakóik elérni."

A gazdasági építmények közül a középhegységi állattartás épületeit rendszerezi Paládi-Kovács Attila, a szálasgabona és takarmányfélék tárolóépítményeit vizsgálja Selmeczi-Kovács Attila tanulmánya. Petercsák Tivadar az erdốmunkások észak-magyarországi építményeihez szolgál érdekes adalékokkal, Bakó Ferenc a pincekutatás újabb eredményeit ismerteti, Sabján Tibor pedig a térség tüzelốberendezéseinek terminológiai problémáival foglalkozik.

A kötetet Balassa Iván elốszava vezeti be és Füzes Endre zárszava áll a végén.

Mindent egybevéve: sokszínú, adatgazdag, felkészült kutatók által írott tanulmánykötetet vehet kezébe az olvasó, amelyben áttekintố írások éppúgy helyet kaptak, mint egy-egy résztémával foglalkozó beszámolók.

Szarvas Zsuzsa 